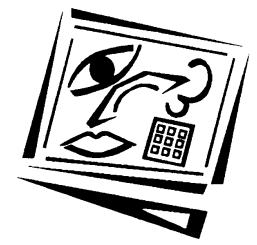

\title{
ICT integration processes in Turkish schools: Using activity theory to study issues and contradictions
}

\author{
Yasemin Demiraslan \\ Iowa State University \\ Yasemin Koçak Usluel \\ Hacettepe University
}

\begin{abstract}
This study used activity theory to examine complex pedagogical, social, and technological issues in ICT integration process at the classroom level. We identified and analysed the contradictions within the activity system and discussed potential effects, which Engeström called 'expansive learning'. We conducted case studies and collected data through semi-structured interviews, video records and observations. Based on the results we concluded that, along with lack of technology and access, the organisational culture, the changing roles of teachers and students with regard to ICT, inflexible timetable curriculum, support of the school administration, the mediator role of ICT coordinator, and collaboration among the teachers were also imperatives that need to be taken into consideration in ICT integration processes.
\end{abstract}

\section{Introduction}

There is a growing interest in the integration of information and communication technologies (ICT) into classrooms as it is assumed that successful integration will offer a wide spectrum of valuable benefits for teaching and learning (Cope \& Ward, 2002; Naidu, Cunnington \& Jasen, 2002). However, although the availability of ICT use in schools has increased, all the gains that were envisaged were not always achieved (Gobbo \& Girardi, 2001). This is because as ICT enters the sociocultural setting of the school, it may trigger changes in the activities, curriculum and interpersonal relationships in the learning environment, and is reciprocally affected by the very changes it causes (Salomon, 1993). Therefore, research studies in ICT need to shift their attention towards the whole configuration of events, activities, contents, and interpersonal processes taking place in the context that ICT is used (Lim, 2002).

In this paper we adopt activity theory (Engeström, 1987), a sociocultural perspective which supports the idea that ICT must be studied within the learning environment and the broader context in which it is situated. By using activity theory as a framework for the analysis, we demonstrate the intimate mechanisms that link ICT, learning and their sociocultural settings (Lim \& Hung, 2003; Lim, 2002). After first outlining central tenets of activity theory, we then apply them to understand the activity system of ICT integration and how contradictions lead to changes in this system. 


\section{Theoretical background: Activity theory}

Activity theory (AT) is a general framework for studying different forms of human activity as development processes (Kuutti, 1996). Within this general context, Engeström (1987) proposed a model (Figure 1) that conceptualises all purposeful human activity as the interaction of the elements: subject, object, tools, community, rules, and division of labour.

In this model of an activity system, the subject refers to the individual or group whose point of view is taken in the analysis of the activity. The object (or objective) is the target of the activity within the system. Tools refer to internal or external mediating artifacts which help to achieve the outcomes of the activity. The community is comprised of one or more people who share the objective with the subject. Rules refer to the explicit and implicit regulations, norms and conventions that constrain actions and interactions within the activity system. The division of labour discusses how tasks are divided horizontally between community members as well as referring to any vertical division of power and status (Center for Activity Theory and Developmental Work Research, 2003).

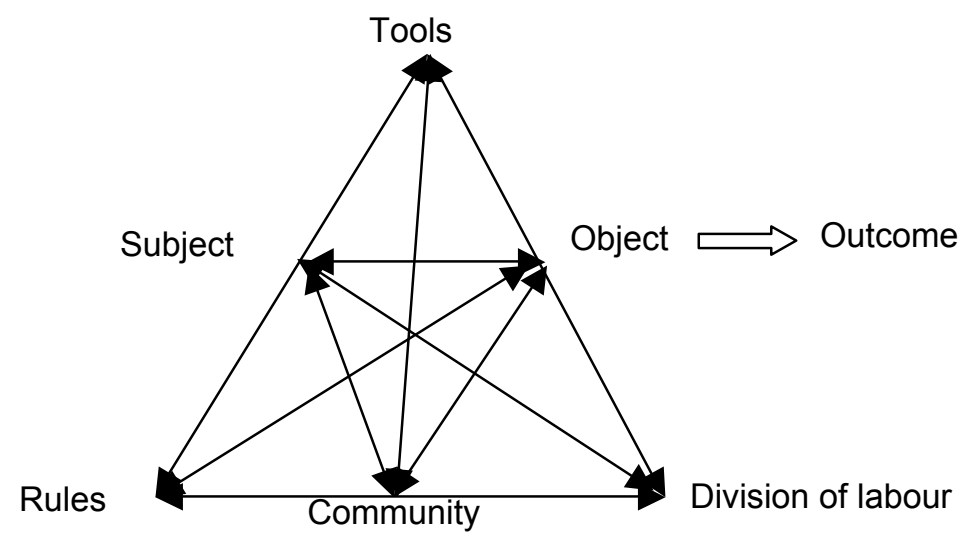

Figure 1. The structure of an activity system

Using this model to analyse the ICT integration, we can map the elements as follows:

Subject Teacher (teaching experience, teaching approach, the personal, administrational and instructional use of ICT, the place of ICT in daily life, the necessity of knowledge and skills related to ICT).

Object The goals of using ICT in teaching-learning process (knowledge and skills acquisition, and problem solving).

Tools ICT and the tools other than ICT, methods which are used, problems which are encountered.

Rules The evaluation criteria, expectations of the teacher, rules of the school.

Community Students, teachers, school administration, ICT coordinator.

Division of The roles and responsibilities of students and teachers, cooperation labour among teachers, the support of administration.

Outcome The reflection of the use of ICT in teaching-learning process to the learning of students and instruction (Demiraslan, 2005). 
AT uses the term contradiction to indicate a misfit within elements, between them, between different activities, or between different developmental phases of a single activity (Sujan, Rizzo \& Pasquini, 2002). According to Engeström (1987, 2001), these contradictions can be problematic but if they are handled in a constructive way, they can also invoke development, through expansive learning. Therefore, in AT contradictions are seen as sources of development; activities are virtually always in the process of working through contradictions.

The introduction of ICT into the activity systems is likely to bring about contradictions. Because these contradictions hinder the effective integration of ICT, they have to be addressed by reassessing and redefining each component of the activity systems (Lim \& Hung, 2003).

\section{ICT in Turkish schools}

The body of authority is the key policy makers in the Ministry of National Education (MONE) for all levels of schools in Turkey. MONE has allocated considerable funding for the use of computers in the teaching and learning process since 1984 when ICT was first introduced to schools. The efforts have been undertaken include in service training of teachers and administrators, courseware and educational material development and training of computer coordinators.

On the other hand, the implementation of any innovation, including ICT is also a responsibility for the schools. Many studies conducted in different primary schools revealed that the use of computers varied due to the differences in school and teacher characteristics (Usluel, Mumcu \& Demiraslan, 2007; Askar \& Usluel, 2003). However, one common point found in these studies was that teachers mostly used ICT in administrative tasks at schools, such as preparation of lecture and unit plans, organising scores and reports of students, but not in instructional tasks such as using a presentation tool during class or using computers for experiments (Usluel, Mumcu \& Demiraslan, 2007; Demiraslan, 2005; Askar \& Usluel, 2003).

Therefore, it is supported by literature that although ICT has entered teachers' lives, their use of ICT for instructional purposes is insufficient (Martins, Steil \& Todesco, 2004; Askar \& Usluel, 2003; Suen \& Szabo, 1998). The lack of ICT in classrooms, lack of knowledge, technical support, and insufficiency of in service training can explain why teachers do not use ICT in their courses. However, the integration of ICT into teachinglearning processes is a complex and multidimensional task including many dynamics such as ICT tools, teachers, students, school administration, educational programs and school culture (Sutherland, 2004; Lim, 2002; Kennewell, 2001). Hence contextual and in depth analyses in the framework of activity theory would be important for developing strategies for the integration of ICT into teaching-learning processes.

\section{Research questions}

In this study, we used AT in order to examine complex pedagogical, social and technological issues in ICT integration process at the classroom level. The research questions can then be formulated as follows.

In the context of ICT integration into teaching-learning processes: 
1. What are the
a. Objects that motivate activity?
b. Tools that mediate the activity?
c. Rules that that regulate actions and interactions of activity?
d. The roles and responsibilities of participants in the activity?
e. The outcomes of activity to students' learning and instruction?

2. What are the contradictions within the activity systems?

\section{Method}

\section{Participants}

This paper draws upon the findings of two case studies conducted in two private primary schools that we named School A and B. The participants were two teachers using ICT in teaching-learning, ICT coordinators and students from each school. "Esra", from School A, was a science teacher having 8 years of teaching experience and "Kenan", from School B, was a mathematics teacher with 4 years of experience in teaching. Two groups of students with 4 and 6 members from School A and a group of students with 6 members from School B were chosen for focus group interviews. The students were between the ages 11-12.

\section{Case study context}

Schools A and B were located in Ankara, the capital city of Turkey. Both schools were technologically rich, above the average of Turkish primary schools, and each had similar characteristics in terms of school management, curriculum, background of students, and teacher qualifications.

In School A, the average class size was 20. It had a computer laboratory with 23 computers connected to Internet and was equipped with data projector, projector screen, printer, scanner and digital video camera. There was also a library with 15 computers having Internet connection. Although there were no computers in classrooms, the science laboratory was equipped with a computer that was linked to the data projector. A specialist was also available to resolve technical problems.

In School B, the average class size was 24 . There were three computer laboratories; 28 computers each in two of the laboratories and 25 computers in the third one. All the computers were Internet connected and each of the laboratories was equipped with data projector, projector screen, printer and scanner. As in School A, there were no computers in classrooms and a specialist was available to resolve technical problems.

\section{Data collection}

In order to triangulate findings, multiple strategies were employed for data collection, including observations of lessons, and interviews with teachers, students, and ICT coordinators. A total of 8 interviews were conducted in Turkish; 2 with each teacher, 2 with the ICT coordinators in charge of ICT (technological access and availability, teachers' and students' ICT use, in service teacher training on ICT, and the school's ICT culture reflecting the attitudes of school administration towards ICT use in classroom as well as the effect of curriculum), and 3 focus group interviews with students. The participants were interviewed for approximately 45 minutes each. The topics of the interviews were tied to the activity theoretical framework. 
Taking the activity system of the classroom as the unit of analysis, 15 lessons in School A and 9 lessons in School B were observed in 2004 spring semester. An observation form including the categories such as technology availability and use, lesson activities, grouping of students during ICT use, and learning content, the role of the teacher, and innovative uses of ICT in the classroom (if any) was developed to guide the observation process. A video camera was used in some lessons in order to minimise the observer effect.

\section{Data analysis}

Tape recorded interviews were transcribed and then analysed in terms of categories drawn from AT, namely: Subject position; tools; object; rules, community and division of labour. The process followed during the content analyses included identifying valid codes by reading the transcripts repeatedly, determining meta-codes that included more than one code, generating activity systems based on the final codes and metacodes, and identifying themes. While analysing the observation data, the frequency of categories that had been observed were marked in the observation form. Similarly, the video analysis was performed through watching the videos repeatedly and then checking the related categories on the observation form. The findings were used to support the content analyses results.

\section{Findings and discussions}

Taking the elements of AT into consideration, the results below were obtained, related to the interactions among ICT, individuals and the context in which the activity was realised. We used a teacher's perspective which means that we chose teacher as the subject in our analysis.

\section{Research question 1a: Object: The goals of teachers about using ICT in teaching-learning processes}

The following questions were posed to the teachers about the object: "What are the most important factors which encourage you to use ICT in your instructional activities? Do you plan to go on using ICT?" (All question and responses have been translated from Turkish by the researchers).

In school A, Esra defined the goals of using ICT as "offering more effective and higher quality education in shorter periods of time, carrying out more activities, increasing the perceptions of children and drawing their attention to the subject owing to visual stimulants".

In school B, Kenan stated that he did not use ICT directly for instructional purposes, but for reinforcement purposes to ensure the permenance of what was learned, and defined the other motives of using ICT as "accustoming students to Internet which [he] regarded as a resource of unlimited information and the indispensability of adapting to developing technology".

Both of the teachers mentioned that they planned to go on using ICT and that they sought ways of using it more effectively. 


\section{Research question 1b: Tools: The tools in ICT integration process, which serve as mediators to achieve the goals}

Four questions were posed to teachers concerning the tools which serve as mediators for the relations between Subject and Object. The first question was as follows: "What are the ICT tools that you use in teaching-learning process?"

Esra mentioned that she "used computer, projector and CD software and wished to use new technological tools such as handheld computers to carry out more science experiments in shorter periods of time". The observations revealed that in 8 courses where ICT was used, PowerPoint presentations were the most common applications. In addition, various software programs on CDs were used to support students' practice, and Internet was used for online quizzes and finding subject related resources.

Kenan said that he "used PowerPoint to present the Internet links related to the subject [he] taught in the classroom". He added that he was able to provide the students with visual information thanks to ICT. It was observed that ICT was used for exercisingpractising activities, playing games and visiting the web sites about the related topics in 5 classes where ICT was used, and that games were regarded as rewards of instructional activities.

Secondly, the following question was asked to the teachers: "Which methods do you apply when using ICT in teaching-learning process?"

Esra stated that the students worked individually when having a quiz on the Internet and as a group when elaborating a booklet or poster, and listened to PowerPoint presentations altogether in the classroom. Moreover, she said that she made use of discovery techniques, question-answer, and problem solving methods. The students emphasised that "learning by playing raised their motivation, group works were effective, they understood the subjects better owing to animations in PowerPoint presentations", however they preferred carrying out activities themselves to teacher explaining the topic directly.

It was observed that the teacher mostly explained the stages of process and students used the ICT in pairs in the lab, or worked in small groups in the classroom where ICT was used to support the content. Group work was also common in the courses where ICT was not used.

Kenan stated that he generally used problem solving methods which were not observed during any of the class observations. The students pointed out that "their involvement in the course would increase when the teacher told the subject and then they practiced on the computer". It was observed that the students worked individually in both the courses where ICT tools were used and were not used. While the teacher acted as a coach and posed questions in the courses where ICT was used, he just taught the learning content in the courses where ICT tools were not used. The observations also revealed that the students were encouraged to strengthen their learning using game based exercises provided by means of Internet links.

In order to identify the difficulties encountered when using ICT in teaching-learning processes, the following question was asked to the teachers: "What difficulties do you encounter when using ICT?" 
Esra mentioned resource problems such as lack of computers and projectors in classrooms. A student who expressed similar opinions said that "they did not have enough computers and access in the school when they needed". Observations confirmed that some students used computers in pairs in the library due to insufficient numbers of computers and there was only one computer in the science laboratory, used solely by the teacher. Nevertheless, the ICT coordinator pointed out that teachers and students had unlimited access to ICT resources. Hence, it is noticeable that there are differences between the viewpoints of the ICT coordinator, and teachers and students in School A concerning access to ICT resources.

Additionally, Esra mentioned that she needed further training to design more effective ICT based activities. She added that she had classroom management problems in the courses where ICT was used since it was difficult to deal with each student individually. Observations confirmed that although the teacher was successful at maintaining order in the classroom in most courses, she had difficulty in responding to the students' questions and helping them individually in the courses where ICT tools were used.

Kenan stated that they had had problems such as "slow Internet connection and insufficiency of computer equipment but currently technical equipment and support were available whenever they needed". Although there was one computer per student, it was observed that the opportunity of students to use computers for extra-class activities was limited. The students also pointed out that they did not have the opportunity to use computers whenever they needed and they wished that more time was dedicated to students' use.

Furthermore, touching upon the problem of delivering the curriculum in time in the courses where ICT was used, Kenan noted that "they were not able to deal with different extra-class activities and that the Ministry of National Education (MONE) should make changes in the curriculum".

It was observed that Kenan had problems in classroom management in the courses where ICT was used due to the difficulty of dealing with each student individually although he did not speak of such a problem during the interview.

\section{Research question 1c: Rules: The rules that regulate actions and interactions of ICT integration into teaching-learning processes}

Four questions were asked to the teachers in order to collect information about the rules which constrain the use of ICT and guide the subject in teaching-learning process.

The following questions were asked to the teachers about the assessment criteria they used in the class: "What are the criteria that you take into consideration when evaluating the learning of your students? Do these criteria change in the courses where you use ICT tools? Or do you develop new criteria for these courses?"

Esra pointed out that she used "such assessment criteria as computer quizzes, oral examination, individual evaluation of each student and multiple choice examinations together, and attached particular importance to performance evaluation". The observations revealed that the students took an online quiz every 15 days and the teacher incorporated group work and assignments into assessment. 
Kenan remarked that "MONE had a determining role in the assessment methods he used in courses, and accordingly, he was obliged to make at least two written examinations". However, he added that he evaluated student term papers which should include Internet research and classroom presentation via PowerPoint. During the observation period, ICT was not used for the purpose of student evaluation.

The following question was put to the teachers to find out their opinions about the ideal classroom environment which enabled the active use of ICT: "What should be the classroom environment to make the most effective use of ICT?"

Esra spoke of "an interactive classroom environment where the individual differences between students were taken into account and which was equipped with various technological tools such as computer, projector, printer and scanner". Students also defined an effective classroom environment as the one which was equipped with technological tools.

Esra added that she expected higher skills from her students in the courses where she used ICT since she believed that "ICT increased student learning especially in abstract subjects thanks to animations and simulations". It was remarkable in the observations that the teacher was clear about her expectations from the students in all the courses and the students were aware of what they were doing. It can be concluded that Esra expected her students to participate in the course more actively and carry out studies based on research and discovery.

Kenan emphasised the importance of "a classroom environment in which there were good computers, fast Internet connection and good software, and where the teacher did not have to deal with technical deficiencies". Moreover, he pointed out that he expected his students to fulfill general assessment criteria in terms of success and not to display undesirable behaviours challenging classroom management. It was observed that there were some ambiguities about Kenan's expectations from his students in the courses where he used ICT compared to the courses in which he did not use ICT. This ambiguity can be due to his use of ICT as a supplement of classroom activities rather than a main part of the teaching-learning process.

The students defined an effective classroom environment as one where "various technologies were used, access to Internet was controlled to provide safety". Additionally, one of the students stated that they would be "more competent computer users owing to a research course carried out under the supervision of a teacher".

The following questions were asked to the teachers about the school rules on using ICT in the teaching-learning process: "Are there any rules imposed by the school about using ICT in teaching-learning process? What is the impact of these rules on using ICT in the courses?"

Esra stated that "a reservation system was used in the school to regulate the access to computers in the library, and she did not have difficulty in access to computers". It was noticeable that Esra, who mentioned that the school administration was not supportive enough and the ICT resources were insufficient, stated that she did not have difficulty in getting access to resources. It can be concluded that since other teachers did not use ICT frequently, Esra did not have problems about using ICT opportunities. 
Kenan pointed out that the school did not have any particular expectations from teachers about using ICT and that the only expectation of the school was carrying out the course in the most effective way and maintaining the school's reputation.

\section{Research question 1d: Division of labour: The roles and responsibilities of participants in ICT integration into the teaching-learning process}

Four questions were asked of teachers to find out the division of labour among participants in the use of ICT in teaching-learning process.

First, the following questions were asked to the teachers to ascertain the impact of ICT on teacher and student roles in the classroom: "Which different roles and responsibilities do your students assume in the courses where you use ICT, compared to the courses where you do not use them? What kind of different roles and responsibilities do you assume?"

Esra noted that "although her workload increased, she had an opportunity to elaborate more activities by using ICT in the classroom". She further mentioned that "owing to ICT tools, the students were involved in the course more actively; they tried to discover new things and even carried out research on their own initiatives". Similarly, the students stated that in the courses where ICT tools were used "they participated in the course more actively, carried out research, prepared PowerPoint presentations based on group work in which they were able to assist each other, and participated in international online projects".

It was observed that the teacher guided the students, gave feedback to their work, and helped them solve problems both in the courses where ICT was used and not used. And the students continuously interacted with each other through sharing their group work. Thus, it can be concluded that the teacher's teaching philosophy had a large impact on the roles and responsibilities of students and teachers in the courses where ICT was used or not used.

Kenan stated that "although the courses in the classroom were generally teacher centered, the students were more active in the courses where ICT was used and they were able to carry out the activities easily under his guidance". He also noted that "ICT ensured the development of social relations thanks to continuous interaction among the students". Similar opinions were expressed by the students who said that "they participated more actively in the courses where ICT was used, they were in more communication with each other and received more assistance from the teacher". On the other hand, it was observed that learning environments were mostly teacher centered in all courses where ICT was used and not used. Although the teacher assisted the students to deal with some activities in courses where ICT was used, he preferred giving the answers to the questions rather than encouraging the students to solve the problems themselves.

The following question was asked to the teachers to find out whether there was a collaboration among the teachers in the school about the use of ICT, and to identify the level of collaboration: "What kind of communication and collaboration is there among teachers in the school about the use of ICT in teaching-learning process?"

Esra stated that "although ICT coordinator helped her when she needed, the communication among teachers was insufficient so that she rarely carried out projects 
with teachers of different subjects". Contrarily, the ICT coordinator said that the projects about the use of ICT in teaching-learning process were carried out with the collaboration of Turkish, social sciences, art, and mathematics teachers and they were presented in school seminars to encourage other teachers to use ICT in their courses. She further explained that most teachers had web sites where they could share their knowledge and they were in communication with each other thanks to forums and egroups.

Kenan stated that "there was communication about the use of ICT within each discipline but the collaboration among the different disciplines was rare". He mentioned that "they had attempted to carry out an interdisciplinary project in the past; however it failed due to the coordination and communication problems among the teachers". The ICT coordinator stated that the teachers who were competent in using technology took advantage of ICT in their courses and were eager to learn new programs and try new techniques, whereas the other teachers did not exert any efforts to use technology in their courses. She added that the efforts of the mathematics teachers served as a model for the other teachers in the school and would encourage them to carry out interdisciplinary projects in following years.

The following questions were asked of teachers to identify the attitude of school administration about the use of ICT: "Does the school administration adopt a supportive attitude about the use of ICT in teaching process? How does the supporting system function?"

Esra stated that "the administration did not hinder any of her efforts and provided financial support, however her efforts were at the individual level since there were no systematic regulations in the school with regard to ICT use". Moreover, she added that "she wished to receive in service training on ICT integration in the classroom, but her demand had not been taken into consideration by the administration yet". On the other hand, the ICT coordinator stated that the school administration was very supportive about the use of ICT in courses, held in service training whenever teachers requested and rewarded teachers' efforts in ICT. Additionally, the students mentioned that "they wished that the school administration provided them with more access to computers whenever they needed".

In School B, Kenan stated that "the school administration provided full support, renewed the computer resources regularly and that their requirements were always met". Similarly, the ICT coordinator explained that the administration adopted a quite supportive attitude, they did not have any problems in supplying technical materials and any demands for in service training would be welcome by the administration. Furthermore, she added that an in service training on the use of ICT was offered in the past; however the teachers were reluctant to participate in offering their workload as an excuse. On the other hand, the students did not find the support of the administration sufficient, stating that "the number of computers in the school was limited and they did not have the opportunity to use them whenever they wanted".

\section{Research question 1e: Outcome: The reflections of ICT integration to students' learning and instruction}

The following questions were posed to the teachers about the outcomes: "What experiences do you have when using ICT? Can you explain the reflections of these experiences on students' learning and instruction?" 
Esra remarked that "she had access to all kinds of written and visual resources, carried out more activities since ICT tools were time-saving, had such alternatives as distance education, and thus, was able to offer an education of higher quality". Moreover, touching upon the limitations of technology, she stated that "the teachers should always have alternative plans or learning activities without being addicted to technology". About Esra's use of ICT in courses, the students said that their interest and motivation for the course increased, they were more active throughout the course, discovered new things owing to the Internet and what they learned was more permanent.

It was observed that although the same learning content was offered to all students, the content was improved by various tools as well as exercises and was supported with subsidiary activities in the courses where ICT was used. All activities raised students' interest and motivation for the course, and contributed to the enrichment and interaction of the learning environment. Nevertheless, longer observations are required to find out to what extent the students' success and effectiveness of teachers' professional tasks is increased by using ICT in the teaching-learning process.

Kenan mentioned that "the courses where ICT was used made the students acquire the skills to work on their own, ensured the active involvement of the students in the course and increased student motivation towards the subject; however the use of ICT did not make any contributions to him except for providing various alternatives". Likewise, the students stated that "they found the courses where ICT was used more enjoyable, the animations and sounds in computer had positive impacts on their learning and they were involved more actively in the course".

It was observed that all the students fulfilled the same learning activities in the course. Although these Internet based activities carried out in the laboratory are not regarded as high level activities, it can be concluded that they promoted the interest and motivation of students for the course and led to an interaction in the learning environment.

\section{Research question 2: Contradictions within the activity systems}

As it can be seen by comparing the types of activity systems identified in the two schools, School A and School B had differences and similarities in the paths they took in terms of ICT integration. In the following section, we present the contradictions within the activity systems in each school.

It may result in a contradiction between Subject-Division of labour ( $a$ ) that the teacher is willing to use ICT in the teaching-learning process and makes use of various technologies in her courses, but finds the support of administration insufficient. Although the ICT coordinator said that the administration adopted a supportive attitude concerning the use of ICT, Esra's viewpoints about the insufficiency of in service training in the school and the lack of systematic regulations bring about a contradiction about the support provided by the school administration.

The insufficiency of ICT resources results in a contradiction between Subject-Tools (b) because the teacher's willingness and efforts to use ICT in the teaching-learning process are hampered by the lack of computers in classroom and laboratory. Hence, adequate resources have to be supplied for teachers to ensure the use of ICT in the courses effectively. 


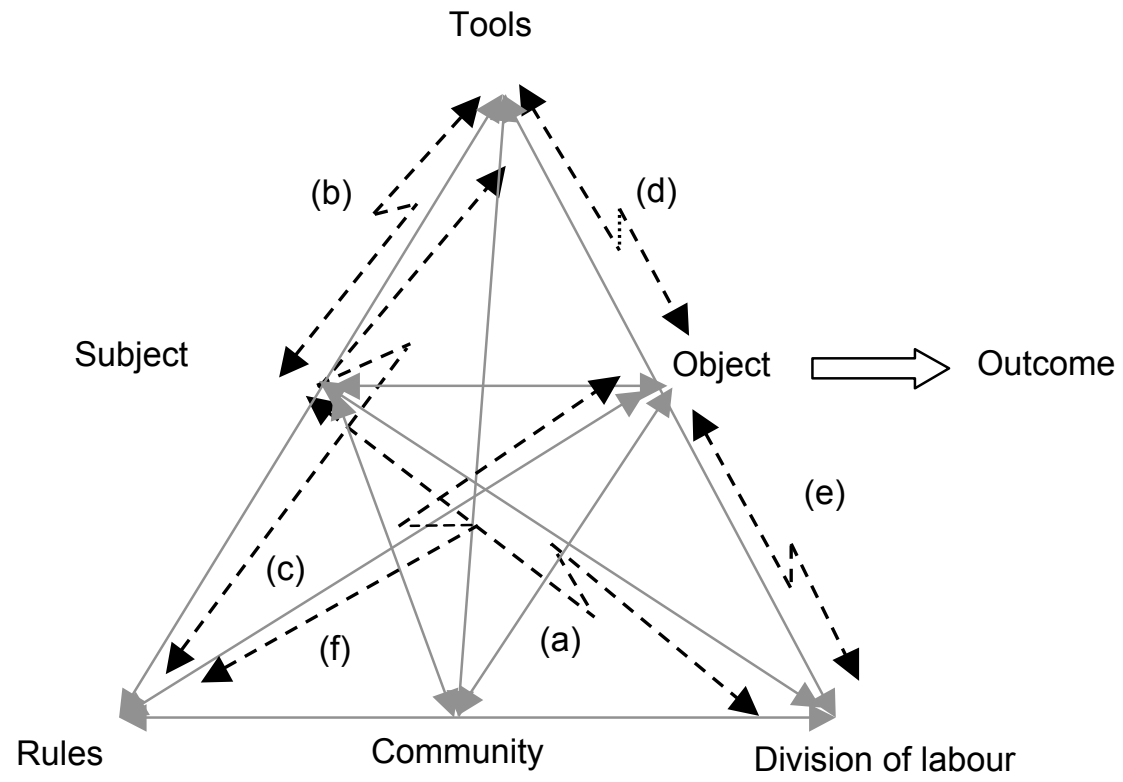

Figure 2: Contradictions within the activity system in School A.

The insufficiency of resources results in the non-fulfillment of teachers' and students' expectations concerning an interactive classroom environment which was defined as a classroom where ICT resources were easily accessible, which brings about a contradiction between Rules-Tools (c). However, the ICT coordinator stated that sufficient resources were provided for the teacher and the students. At this point, it is suggested that the ICT coordinator establish closer relations with teachers, understand their needs, and serve as a bridge between the school administration and teachers to facilitate the solutions of problems. Additionally, an ICT policy including the supply of computers in classrooms and the accessibility of resources can be implemented in the school with the leadership of ICT coordinator.

The challenges of classroom management in the courses where ICT is used lead to a significant contradiction between the use of ICT in the teaching-learning process and its objective to promote students' learning and the quality of teaching, that is to say, between Tools-Object (d). At this point, in service training offered to teachers will contribute to the integration process by explaining teachers which pedagogy they should adopt and what kinds of strategies they should develop in view of potential problems in the courses where they use ICT.

The lack of adequate communication and collaboration among the teachers in the school over the use of ICT brings about a contradiction between Object-Division of labour (e). It is noticeable from the interviews that there is not any interdisciplinary collaboration among the teachers with regard to the use of ICT in courses. However, it is important that the effective functioning of integration process is achieved with interdisciplinary endeavors which require collective participation of all units in the school. The efforts of only one teacher to use ICT in her courses will not ensure the institutionalisation of the process, but remain as an individual initiative. Hence, it can be concluded that the support of the administration and collaboration among teachers 
play an important role in the institutionalisation of the ICT integration process. In addition, the obligatory disregard of ICT in assessment because of standard based examinations and an inflexible instructional program causes a contradiction between Rules-Object (f). Regulations are required to integrate ICT into curriculum in the field of assessment.

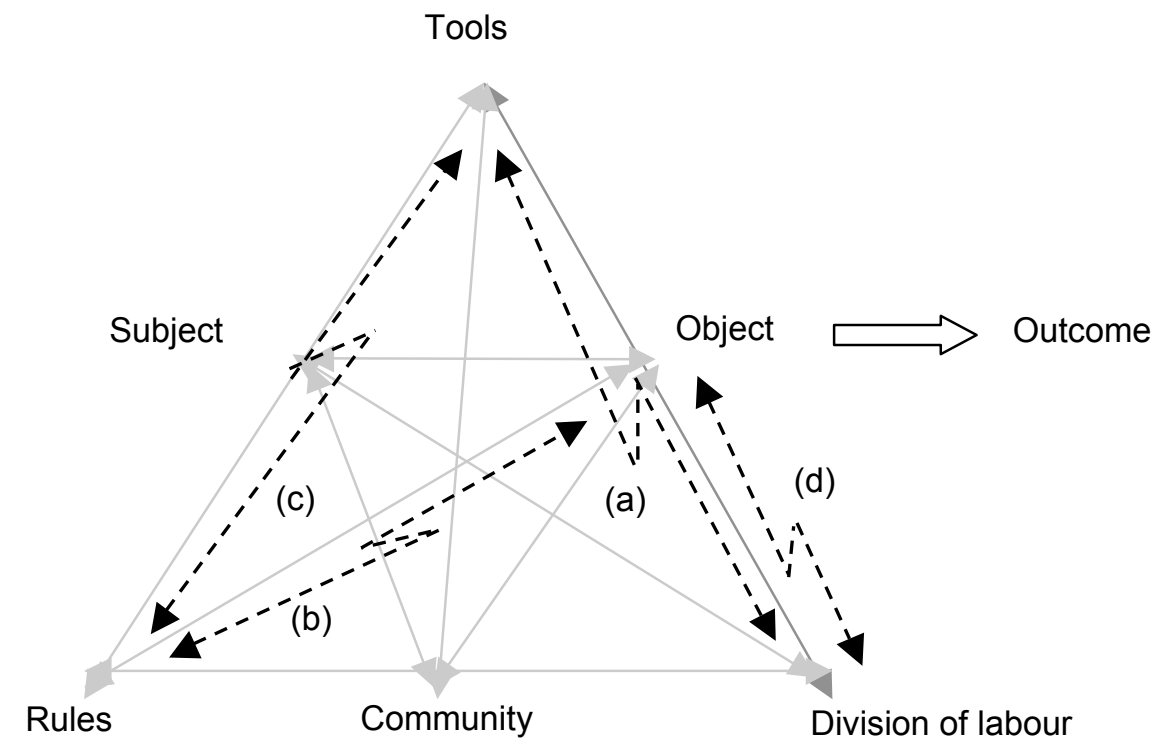

Figure 3: Contradictions within the activity system in School B.

There is a contradiction between Tools and Division of labour (a) since Kenan adopts a teacher centred approach in teaching and cannot detach from the role of traditional teacher though he gradually holds a guiding position with the use of ICT. His thought that ICT does not affect teacher-student relations considerably may result from not using ICT to support student learning but using it as an add on to the regular classroom activities. On the other hand, the students mentioned that they preferred collaborative activities with the guidance of teacher. Hence, it is of particular importance that the teacher makes considerable changes in his pedagogy and adopts new roles and responsibilities, such as acting more as a guide and letting students be more responsible for their own learning.

Kenan spoke of the obligation to deliver the curriculum in time and stated that lack of time hindered the fulfillment of extra-class activities, and thus, he found the current ICT based activities sufficient, which results in contradictions between Rules-Object (b). To this end, a systematic process of change and technology oriented regulations in the curriculum are required in the school. Given that curricula are organised by MONE, it is obvious that these regulations must be imposed at the national level.

Furthermore, contradictions between Rules-Tools (c) arouse since Kenan uses traditional assessment methods due to the obligation to comply with general success criteria such as standard based tests held by MONE throughout the nation. It is recommended that the school revises all its rules on assessment and that the groups who have a determining role in the educational policies at the national level introduce new ICT centred policies. 
Similar to School A, the lack of sufficient communication and collaboration about the use of ICT among teachers in School B results in a contradiction between ObjectDivision of labour $(d)$. Although the heavy course load of teachers is defined as a significant motive behind the lack of collaboration, it is believed that teachers can carry out interdisciplinary projects with the support of the ICT coordinator and the school administration so as to assure the effectiveness of integration process.

\section{Conclusions}

ICT integration is, after all, both the tools and the methods used in teaching (Li \& Bratt, 2004). To understand how teachers integrate ICT into the teaching-learning process requires an analysis of the activity systems in which they are embedded, and an analysis of the contradictions inherent within activities. Therefore, by adopting an activity theoretical approach to the study, not only can we understand the various processes within and between the elements of activity system, but also we can pinpoint problem areas to be addressed and construct potential effects of contradictions in ICT integration process. In this paper, we used an activity theory framework for understanding and describing experiences of students and teachers when using ICT and the contradictions that occurred in the ICT integration process.

Given the activity systems in School A and School B, it was noticed that both the teacher (Esra) and the students in School A emphasised the lack of technological equipment and computer access. The teacher (Kenan) in School B did not mention any difficulties except for simple technical problems, whereas the students found the computer opportunities in the school inadequate. Furthermore, Esra stated that the school administration did not provide her with sufficient support including in service training and that her efforts did not go beyond individual initiatives. Esra regarded this attitude of the administration as a significant problem that hampered her willingness to introduce technology in her classroom. On the other hand, Kenan explained the obligation to deliver the curriculum in time and stated that lack of time hindered the fulfillment of extra-class activities and thus he found the current ICT related activities sufficient.

These findings were supported by the literature. The common point of all studies about the integration of ICT into school programs is that teachers should be equipped with the required knowledge and skills to ensure the effective integration of ICT into the teaching-learning process (Galanouli, Murphy \& Gardner, 2004; Jedeskog \& Nissen, 2004; Cope \& Ward, 2002). In other words, to be able to use ICT in the courses effectively, teachers should be aware of its potential, select tools and methods which are appropriate for the needs of students, design their teaching methods effectively, and develop new teaching strategies. Furthermore, it is essential for the teachers to know and apply classroom management rules in order to cope with problems encountered in technology aided learning environments (Herzig, 2004; Gobbo \& Girardi, 2001). Although access to technology is still a major obstacle to the teachers in developing countries as in this study, it is the skill and attitude of the teacher that determines the effectiveness of technology integration into the classroom. Therefore, not only the accessibility of equipment should be ensured; but also teachers should be provided with the opportunities of lifelong training and development about ICT skills.

Comparing the contradictions within the activity systems in School A and School B, it was found out that there are more contradictions in the activity system of School A. In 
fact, it was observed in School A that Esra was quite willing to use ICT in her courses, had adequate knowledge about ICT and carried out activities which served the integration. However, it was noticed that such factors as the insufficiency of in service training and resources, the attitude of the administration, the school rules and the lack of sufficient collaboration among the teachers in the school bring about contradictions among the elements in the activity system. In School B, the school was more equipped with ICT resources, which might lead to fewer contradictions in activity system. However, the fact that Kenan preferred basic drill-practice exercises to promote the motivation of children rather than applications targeted at the integration of ICT into the teaching-learning process could be a much more important factor in fewer numbers of contradictions in School B.

Additionally, these two schools were selected based on the information that there were enough computers for use by students and teachers, and that teachers used ICT regularly in their classroom. However, the findings indicated that either the computer access or the way of using ICT in the teaching-learning process was problematic in terms of effective ICT integration in each school. One of the reasons may be due to the lack of a shared understanding in the school community about the purposes of using ICT in the classroom. Therefore, it is highly important that the goals of introducing ICT into a learning setting be aligned with the mission and the values of the schools.

Although we report findings from only two cases, the deeply contextual data collected enabled us to make conclusions, which we feel, will hold across other studies of this kind. The findings indicate that the use of ICT as a teaching-learning tool does indeed force a shift in the activity system, transforming traditional behaviours, leading to contradictions in and between systems and, consequently, forcing changes in and between systems. Based on the results, we conclude that, along with lack of technology and access, the organisational culture, the changing roles of teacher and students with regard to ICT, inflexible timetable curriculum, the support of the school administration, the mediator role of an ICT coordinator and the collaboration among the teachers were also imperatives that need to be taken into consideration in ICT integration processes.

Finally, it is valuable to emphasise that activity theory is a decriptive theory which helps us to understand the culture and the context of a learning environment and the underlying interactions in this context. Therefore, in this study, we used activity theory concepts and language to describe the changes brought by ICT use in the classroom, rather than to prescribe changes or design solutions for effective ICT integration in teaching and learning. Future research using empirical methodologies and large sample sizes reflecting the diversity of schools in the community can be conducted in order to provide more detailed prescriptives for effective integration processes.

\section{References}

Askar, P. \& Usluel, Y. K. (2003). A longitudinal study related to the rate of adoption of computers: Comparison of three schools. Hacettepe University Journal of Education, 24, 15-25.

Center for Activity Theory and Developmental Work Research (2003). The activity system. http: / / www.edu.helsinki.fi/activity/pages/chatanddwr/activitysystem/ [viewed 12 Nov 2003, verified 11 Aug 2008]. 
Cope, C. \& Ward, P. (2002). Integrating learning technology into classrooms: The importance of teachers' perceptions. Educational Technology \& Society, 5(1), 67-74. http: / / www.ifets.info/journals /5_1/ cope.html

Demiraslan, Y. (2005). Analyzing the integration of information and communication technologies into teaching-learning process according to activity theory. Unpublished dissertation. Ankara: Hacettepe University.

Engeström, Y. (2001). Expansive learning at work: Toward an activity-theoretical reconceptualization. Journal of Education and Work, 14(1), 133-156.

Engeström, Y. (1987). Learning by expanding: An activity-theoretical approach to developmental research. [viewed 5 Mar 2005, verified 11 Aug 2008] http: / / communication.ucsd.edu/LCHC/MCA/Paper/Engestrom/expanding/toc.htm

Galanouli, D., Murphy, C. \& Gardner, J. (2004). Teachers' perceptions of the effectiveness of ICTcompetence training. Computers $\mathcal{E}$ Education, 43, 63-79.

Gobbo, C. \& Girardi, M. (2001). Teachers' beliefs and integration of information and communications technology in Italian schools. Journal of Information Technology for Teacher Education, 10(1\&2), 63-85. [verified 11 Aug 2008] http: / / www.informaworld.com/ smpp/ content $\sim$ content $=\mathrm{a} 751267195 \sim \mathrm{db}=\mathrm{all} \sim$ order $=$ page

Herzig, R. G. M. (2004). Technology and its impact in the classroom. Computers $\mathcal{E}$ Education, 42(2), 111-131.

Jedeskog, G. \& Nissen, J. (2004). ICT in the classroom: Is doing more important than knowing? Education and Information Technologies, 9(1), 37-45.

Kennewell, S. (2001). Using affordances and constraints to evaluate the use of information and communications technology in teaching and learning. Journal of Information Technology for Teacher Education, 10(1\&2), 101-116. [verified 11 Aug 2008]

http: / / www.informaworld.com/smpp/ content $\sim$ content $=\mathrm{a} 739086211 \sim \mathrm{db}=\mathrm{all} \sim$ order $=$ page

Kuutti, K. (1996). Activity theory as a potential framework for human-computer interaction research. In B. A. Nardi (Ed.) Context and consciousness: Activity theory and human-computer interaction, Cambridge, MA: The MIT Press, 17-44.

Li, J. Z. \& Bratt, S. E. (2004). Activity theory as tool for analyzing asynchronous learning networks (ALN). In W. Liu, Y. Shi \& Q. Li (Eds), Advances in web-based learning, ICWL 2004: Proceedings Third International Conference. Beijing, 8-11 August. Berlin: Springer

Lim, C. P. \& Hung, D. (2003). An activity theory approach to research of ICT integration in Singapore schools. Computers \& Education, 41(1), 49-63.

Lim, C. P. (2002). A theoretical framework for the study of ICT in schools: A proposal. British Journal of Educational Technology, 33(4), 411-421.

Martins, C. B. M. J., Steil, A. V. \& Todesco, J. L. (2004). Factors influencing the adoption of the Internet as a teaching tool at foreign language schools. Computers $\mathcal{E}$ Education, 42, 353-374.

Naidu, S., Cunnington, D. \& Jasen, C. (2002). The experience of practitioners with technologyenhanced teaching and learning. Educational Technology \& Society, 5(1), 23-34.

http:/ / www.ifets.info/journals/5_1/naidu.html 
Salomon, G. (1993). On the nature of pedagogic computer tools: The case of the Writing Partner. In S. P. Lajoie \& S. J. Derry (Eds), Computers as cognitive tools. New Jersey: Lawrence Erlbaum Associates, 179-196.

Sujan, M. A., Rizzo, A. \& Pasquini, A. (2002). Contradictions and critical issues during system evolution. In Proceedings of the 2002 ACM Symposium on Applied Computing, Madrid (pp.711715). New York: ACM.

Sutherland, R. (2004). Designs for learning: ICT and knowledge in the classroom. Computers $\mathcal{E}$ Education, 43(1\&2), 5-16.

Suen, C. \& Szabo, M. (1998). A study of the impact of a school district computer technology program on adoption of educational technology. [viewed 30 Nov 2005, verified 11 Aug 2008] http: / / www.quasar.ualberta.ca/edmedia/Suenszabo.html

Usluel, Y., Mumcu, F. \& Demiraslan, Y. (2007). ICT in teaching-learning process: Teachers' views on the integration of ICT and on the perceived obstacles to this integration. Hacettepe University Journal of Education, 32, 164-179.

\author{
Yasemin Demiraslan \\ Department of Curriculum \& Instruction, Iowa State University \\ N131 Lagomarcino Hall, Ames, Iowa 50011 USA \\ Email: yasemind@iastate.edu \\ Yasemin Kocak Usluel \\ Department of Computer Education and Instructional Technology \\ Faculty of Education, Hacettepe University, 06800, Beytepe, Ankara, Turkey \\ Email: kocak@hacettepe.edu.tr
}

